\title{
BERKABUNG DI MEDIA SOSIAL: PERSEPSI PEMBERITAAN KASUS KEMATIAN ARTIS KPOP DI INSTAGRAM
}

\author{
Nadiah Viora Salsabila ${ }^{1}$, Niken Febrina Ernungtyas ${ }^{2}$ \\ 1)2) Sekolah Tinggi IImu Komunikasi Inter Studi \\ niken@stikom.interstudi.edu
}

Received: 7 February 2020 | Reviewed: 9 February 2020 | Accepted: 25 February 2020

\begin{abstract}
ABSTRAK
Setiap kehidupan selalu bersinggungan dengan internet, termasuk fase duka cita. Seseorang yang telah ditinggalkan selamanya oleh orang tersayang maka memiliki sifat kedukaan telah berpindah ke media online dengan berbagai cara dan beberapa aspek kematian seperti duka daring di media sosial. Media sosial merupakan platform melalui jaringan internet yang dapat digunakan untuk membuat profil berbagi konten digital yang dibuat dalam bentuk teks, foto, grafik, atau video dalam komunitas pengguna jaringan yang dapat merespons konten tersebut. Media sosial menjadi perantara berkabung bagi pengguna yang terpisah ruang dan jarak. Penelitian ini bertujuan mendeksripsikan persepsi terhadap informasi duka yang beredar di media sosial. Kedukaan yang menjadi fokus pada penelitian ini yaitu artis Kpop dari Korea Selatan bernama Choi Jin Ri atau Sulli mantan personil girl band $F(x)$. Sulli meninggal karena kasus bunuh diri akibat perundungungan yang dialami di media sosial seperti hujatan, hinaan, bahkan berkomentar negatif (trolling). Penelitian ini menggunakan paradigm konstruktivisme dan pendekatan kualitatif untuk memahami fenomena berkabung pada media sosial. Pengumpulan data dilakukan dengan wawancara tiga orang remaja yang mengetahui kasus tersebut. Setelah koding kualitatif pada transkrip wawancara, didapatkan tiga temuan utama. Pertama, berita dukacita di Instagram menjadi popular, viral dan booming. Kedua, warganet merasakan emosional ketika melihat informasi tersebut di Instagram. Ketiga, warganet bersimpati atas tindakan perundungan yang dialami oleh Sulli
\end{abstract}

Kata Kunci : Media Sosial, Berkabung, Emosional, Persepsi

Korespondensi:

Sekolah Tinggi Ilmu Komunikasi Inter Studi

Jl. Wijaya II No. 62 Kebayoran Baru, Jakarta

E-mail: niken@stikom.interstudi.edu 


\begin{abstract}
Every life is always in contact with the internet, including the phase of grief. Someone who has been left forever by someone dear then has the nature of grief has moved to the online media in various ways and several aspects of death such as mourning on social media. Social media is a platform through the internet network that can be used to create digital content sharing profiles created in the form of text, photos, graphics, or videos in the network user community that can respond to that content. Social media mediates mourning for users who are separated by space and distance. This study aims to describe the perceptions of the grief information circulating on social media. The grief that is the focus of this study is the K-pop artist from South Korea named Choi Jin Ri or Sulli, a former member of the girl band F (x). Sulli passed away of suicide due to bullying on social media such as blasphemy, insults, and even negative comments (trolling). This study uses a constructivist paradigm and a qualitative approach to understand the phenomenon of mourning on social media. Data collection was collected by interviewing three teenagers who knew the case. After qualitative coding on the interview transcript, three main findings were obtained. First, the news of grief on Instagram became popular, viral and booming. Second, netizens feel emotional when they see that information on Instagram. Third, netizens sympathize with acts of abuse experienced by $\underline{\text { Sulli }}$
\end{abstract}

Keywords: Social Media, Mourning, Emotional, Perception

\title{
PENDAHULUAN
}

Penelitan ini bertujuan untuk membuat mengeksplorasi pemberitaan serta informasi yang beredar di media sosial ketika dalam keadaan berkabung. Setiap kehidupan selalu bersinggungan dengan internet, termasuk fase duka cita. Seseorang yang telah ditinggalkan selamanya oleh orang tersayang maka memiliki sifat kedukaan telah berpindah ke media online dengan berbagai cara dan beberapa aspek kematian seperti duka daring. Halaman media sosial milik seseorang yang telah meninggal sering menjadi halaman peringatan. Teman, keluarga dan penggemar dalam beberapa kasus seperti mengunjungi halaman dan meninggalkan pesan. Seseorang menemukan sebagai cara yang nyaman untuk berbagi duka ketika mereka tidak dapat menghadiri layanan pemakaman atau hari peringatan. Halaman peringatan online ini juga menjadi ruang komunitas untuk mendiskusikan almarhum. Meskipun sebagian besar komentar masuk ketika orang mengetahui tentang kematian seseorang, sekitar $40 \%$ orang yang telah berpartisipasi dalam diskusi telah kembali berbulan-bulan kemudian untuk membaca dan mengirim komentar (Moore, Magee, Gamreklidze, \& Kowalewski, 2019). 
Kesedihan karena duka cita merupakan salah satu proses batin. Kesedihan tersebut diungkapkan pada halaman media sosial. Orang yang berduka mencari makna yang tidak dipikirkan. Berkabung merupakan kegiatan interpretatif dan komunikasif dalam menetapkan makna hidup dan mati seseorang yang meninggal, serta status seseorang yang meninggal lebih luas dengan kehilangan (Neimeyer, Klass, \& Dennis, 2014). Media sosial telah menempatkan praktik berkabung di dalam kehidupan sehari-hari dengan cara asumsi yang dibuat tentang pengungkapan informasi kepada publik yang sering ditafsirkan. Peneliti akan membahas bagaimana cara membayangkan duka online dalam studi empiris dan bagaimana konsepsi tersebut dalam menginformasikan keputusan metodologis dan etis. Praktik-praktik berkabung online sangat dipermasalahkan dalam hal privasi dan publisitas dalam literatur saat ini, masalah etika yang berkaitan dengan analisis mereka hampir tidak pernah dibahas dalam penelitian empiris (Moore et al., 2019).

Penggunaan media sosial Instagram dapat digunakan dalam menganalisis foto-foto yang yang dibagikan melalui profil publik berupa gambar yang diunggah dengan mengomunikasikan keadaan secara emosional dan memungkinkan untuk memposisikan ulang pengalaman pemakaman di antara jaringan yang lebih luas terutama di kenalan, teman dan keluarga. Bahwa berbagi foto melalui media sosial Instagram memiliki jaringan yang luas dalam pelaksanaan peringatan secara formal dilembagakan ke informal. Secara langsung berkontribusi pada pemahaman yang memperhatikan bahasa sehari-hari di media sosial Instagram akan terkait dengan tradisi dan konteks perkabungan. Pemahaman mengenai kematian berkontribusi dengan media sosial dimobilisasikan terkait kematian, serta perbedaan yang dibuat oleh platform media yang berbeda dengan tempat serta peristiwa (Gibbs, Meese, Arnold, Nansen, \& Carter, 2015). Media sosial adalah platform melalui jaringan internet yang dapat digunakan untuk membuat profil berbagi konten digital yang dibuat dalam bentuk teks, foto, grafik, atau video dalam komunitas pengguna jaringan yang dapat merespons konten tersebut.

Karena interaksi dan emosi, platform media sosial merupakan ruang sosial yang mudah diakses untuk berbagi, diskusi, dan negosiasi informasi tentang kematian, kesedihan, kehilangan, dan duka. Ruang-ruang praktik berkabung yang terjadi tidak sepenuhnya terpisah dari ruang sosial lain, tetapi memberikan perluasan ke ruang berkabung offline dengan saling terkait (Christensen \& Gotved, 2015). Banyak praktik berkabung di media sosial dalam membuat situs 
memorial virtual dan berbagi kenangan dengan praktik yang menghubungkan offline ke konteks online (Giaxoglou, 2013). Karena lingkungan media sosial memiliki khas berupa fitur teknologi dan norma-norma yang mendominasi, praktik berkabung yang terjadi di media sosial dapat berbeda dalam beberapa hal dengan praktik berkabung tradisional. Media sosial merupakan ruang sosial baru di mana topik kematian, kehilangan, dan berkabung semakin ditemui dan dinegosiasikan. Pengguna mungkin terlibat dalam praktik berkabung sendiri atau dihadapkan dengan duka pengguna lain selama penggunaan media sosial sehari-hari. Keberadaan berkabung di media sosial menghadirkan tantangan bagi pengguna dan meningkatkan kebutuhan akan norma tentang cara terlibat dalam praktik berkabung online dan bagaimana bereaksi terhadap ekspresi kesedihan dan berkabung. Tetapi tidak semua ekspresi media sosial seputar kematian diterima dengan baik atau dijelaskan. Berkabung di media sosial merupakan bentuk berkabung yang baru dikonfigurasi ulang dan bukan yang sama sekali baru (Giaxoglou, 2013).

Baru-baru ini muncul lingkungan online sebagai situs untuk perluasan kematian dan duka sementara, spasial dan sosial (Brubaker, Hayes, \& Dourish, 2013) menyerukan studi sistematis ritual digital pasca kematian berkabung. Penelitian di bidang ini sedang berkembang di seluruh disiplin ilmu thanatologi, psikologi, sosiologi, studi permainan, dan studi wacana dan komunikasi, membuka kemungkinan yang menarik untuk pemupukan silang lintas disiplin yang dapat berkontribusi pada pengembangan pemahaman menyeluruh tentang kematian, sekarat di masa techno-sosial. Praktik berkabung di media sosial adalah praktik yang dimediasi dengan platform media sosial yang menyediakan serangkaian fitur teknologi di mana pengguna bertindak. Situs berkabung dapat menjelaskan mengenai kehidupan almarhum dan kehidupan setelah kematiannya. Termasuk berbagi kenangan dengan memposting konten teks atau visual, membuat situs memorial virtual dengan membuat halaman peringatan dan berkomunikasi dengan yang berduka lainnya melalui komentar dan menyukai postingan (Bailey, Bell, \& Kennedy, 2015).

Ketika pengguna berduka atas kematian orang yang mereka cintai di situs yang secara khusus dirancang untuk awalnya tidak terkait dengan berkabung kemungkinan bagi pengguna lain untuk menemukan konten yang berkaitan dengan berkabung selama penggunaan media sehari-hari mereka meningkat. Selain secara aktif terlibat dalam praktik berkabung dan "komunikasi dari, ke, dan tentang orang mati" (Brubaker et al., 2013). Orang- orang yang sedang berkabung 
menggunakan media sosial sebagai alat untuk berkomunikasi dalam memberikan informasi mengenai seputar kematian. Media sosial merupakan ruang sosial baru di mana topik kematian, kehilangan, dan berkabung semakin ditemui dan dinegosiasikan. Pengguna mungkin terlibat dalam praktik berkabung sendiri atau dihadapkan dengan duka pengguna lain selama penggunaan media sosial sehari-hari.

Keberadaan berkabung di media sosial menghadirkan tantangan bagi pengguna dan meningkatkan kebutuhan akan norma tentang cara terlibat dalam praktik berkabung online dan bagaimana bereaksi terhadap ekspresi kesedihan dan berkabung. Model kesedihan menyarankan berkabung berurusan dengan kehilangan kehidupan, stress, penyesuaian, menghindari atau gangguan, dan menetapkan peran baru. Bahwa proses di saat-saat sedih dan kehilangan terdiri dari langkah-langkah duka berlangsung selama di saat-saat sedih dan kehilangan, perilaku aspek kognitif, emosional, fisik, dan reaksi-reaksi rohani oleh media sosial berkabung. Proses pemakaman yang menganalisis foto-foto dibagikan di profil publik. Sebagian foto berkabung yang diunggah sering mengkomunikasikan perasaan emosional seseorang, dan memungkinkan mereka untuk memposisikan ulang pengalaman pemakaman mereka terhadap lingkungan kenalan, teman dan keluarga. Pemanfaatan situs jaringan sosial telah menjadi situs umum yang mudah dijangkau dan diakses dalam mengungkapan duka cita. Berduka melalui media sosial memiliki pertentangan terhadap kematian resmi, bahwa ekspresi media sosial seperti merendahkan perasaan emosi duka. Duka cita merupakan perkabungan yang memiliki sebuah rasa kehilangan dan kesedihan karena adanya perpisahan dengan orang yang dicinta.

Postingan foto dan komentar di media sosial merupakan pengungkapan peringatan hari kematian dan memberikan rasa hormat bagi orang yang telah meninggal. Seseorang yang merasakan kehilangan harus menerima kenyataan bahwa kematian benar-benar terjadi (Kakar \& Oberoi, 2016). Adapun alasan orang berduka menggunakan media sosial untuk menggambarkan rasa kesedihan yang diungkapkan secara virtual. Berduka cita melalui jaringan internet menjadi sebuah simbol dalam masyarakat. Peneliti akan melakukan penelitian terhadap kasus bully melalui media sosial yang berada di Negara Korea Selatan. Banyaknya kasus bunuh diri terhadap artis Kpop akibat depresi karena sering mendapatkan pesan bully online berupa hujatan, hinaan, bahkan berkomentar negatif (trolling). Seperti kasus Choi Jin Ri mantan personil girl band F(x) yang akrab dipanggil Sulli. Sulli sering mendapatkan serangan komentar daring serta menderita 
sindrom popularitas ekstrem dan gangguan panik yang menjadi penyebab hengkang dari grup $\mathrm{F}(\mathrm{x})$. Setelah hengkang dari girl band F(x), Sulli tetap melanjutkan solo karir dan fokus pada akting drama. Di solo karirnya, Sulli melewati berbagai macam kontroversi. Sulli memiliki gangguan mental berupa fobia sosial yang membuatnya merasa takut karena terus menerus diawasi oleh orang lain. Gangguan seperti ini mengakibatkan aktivitas sehari-hari menjadi terganggu. Apabila gangguan ini tidak segera ditangan, maka akan menyebabkan penderitanya merasa rendah diri serta sulit berinteraksi dengan orang lain. Banyaknya warganet yang memberikan kritikan mengenai perilaku dan hanya menilai seseorang dari penampilannya saja, tanpa memberikan saran dan komentar positif.

\section{KAJIAN TEORI}

Media merupakan sebuah pengantar untuk menyalurkan sebuah pesan atau informasi ke penerima pesan. Dengan adanya media, masyarakat dapat melihat kondisi lingkungan scara lebih jauh untuk memahami pengalaman, menyampaikan informasi berupa opini audiens. Komunikasi berupa ide, gagasan serta pesan yang disampaikan kepada pihak lain. Komunikasi dapat dilakukan secara lisan dan verbal. Media komunikasi dapat digunakan untuk perantara penyampaian pesan dari komunikator ke komunikan atau khalayak. Media komunikasi memiliki peranan penting dalam kehidupan masyarakat, karena memiliki tujuan dalam menyebarkan informasi agar lebih efisien. Dengan adanya proses komunikasi, masyarakat dapat membuat sebuah hubungan, kelompok, organisasi yang menciptakan pesan dan respon untuk beradaptasi satu sama lain. Sebagai makhluk sosial, seseorang akan selalu ingin berhubungan dengan yang lainnya. Serta memiliki keinginan untuk mengetahui keadaan di lingkungan sekitarnya, bahkan mengetahui hal apa yang sedang terjadi dengan rasa keingintahuan membuat seseorang perlu berkomunikasi.

Dalam hidup bermasyarakat, jika seseorang tidak pernah berkomunikasi dengan orang lain, maka akan berpengaruh terhadap kondisi mental yang akhirnya membuat kehilangan keseimbangan jiwa. Karena, komunikasi merupakan bagian dari kehidupan manusia, sepanjang hidupnya seseorang perlu berkomunikasi. Bullying adalah fenomena yang terjadi lintas budaya, jenis kelamin, usia, dan ras. Perilaku yang merupakan bullying tersebar luas, dan mereka dicirikan

oleh ketidakseimbangan kekuatan, niat untuk mencelakakan, dan pengulangan seiring waktu (Swearer, Collins, \& Berry, 2012). Media sosial adalah platform dengan jaringan internet untuk 
membuat profil untuk berbagi konten digital yang dibuat dalam bentuk teks, foto, grafik, atau video dalam komunitas pengguna jaringan yang dapat merespons konten tersebut.

Karena interaksi dan emosi, platform media sosial merupakan ruang sosial yang mudah diakses untuk berbagi, diskusi, dan negosiasi informasi tentang kematian, kesedihan, kehilangan, dan duka. Ruang-ruang praktik berkabung yang terjadi tidak sepenuhnya terpisah dari ruang sosial lain, tetapi memberikan perluasan ke ruang berkabung offline dengan saling terkait (Christensen \& Gotved, 2015). Jejaring online melalui media sosial dimulai sebagai trend di kalangan anak muda yang memahami internet dan telah menjadi suatu budaya dengan mengubah cara berpikir tentang berkomunikasi dengan keluarga dan teman-teman. Menganalisis komunikasi melalui media sosial serta komunikasi visual terkait dengan berbagi foto, audio dan video yang mengeksplorasi mengenai infromasi kedukaan. Berbagai jaringan sosial, seperti Myspace dan Facebook yang memiliki fitur berupa profil dari orang yang meninggal menjadi profil publik. Sedangkan, media sosial Instagram tidak memiliki ruang bagi orang-orang yang berkabung. Karena memiliki fitur postingan yang terbatas serta terdapat ruang publik (Meese et al., 2015). Paradigma konstruktivisme menyatakan bahwa individu menginterpretasikan dan beraksi dalam kategori konseptual.

\section{METODE PENELITIAN}

Penelitian ini menggunakan paradigm konstruktivisme untuk memahami fenomena berkabung pada media sosial. Sedangkan pendekatan yang digunakan adalah kualitatif untuk memahami persepsi informan terkait fenomena berkabung atas kematian salah satu artis Kpop di

media sosial. Metode deskriptif kualitatif bertujuan untuk menjelaskan secara mendalam tentang bagaimana generasi muda menanggapi informasi mengenai komunikasi interpersonal melalui media sosial berkabung perihal kematian seorang penyanyi Choi Jin Ri yang akrab di panggil Sulli. Dengan teknik mengumpulkan data serta melakukan tahapan dalam wawancara mendalam (Depth Interview) dan menganalisis seberapa banyak informan yang mengetahui kasus ini melalui media sosial mengenai media berkabung. Penelitian ini melibatkan tiga orang informan yaitu, MDL, AZN, dan II. Ketiga informan ini dipilih karena mewakili generasi millennial dan mengetahui kasus kematian Sulli. 
Peneliti memilih generasi muda berusia 17 tahun, karena orang yang lahir berkisaran tahun 2002an. Millennial adalah generasi muda. Millennials atau generasi muda yang dianggap berbeda dengan generasi sebelumnya, terutama dalam hal teknologi. Metode penelitian analisis data ini menggunakan cara dengan merangkum hal-hal yang penting, memilih hal-hal pokok serta peneliti akan mengkaji data serta menyusun informasi berbentuk table. Penelitian ini berupa wawancara. Wawancara adalah percakapan dengan maksud tertentu. Sebuah percakapan yang dapat dilakukan oleh dua pihak (interview). Wawancara merupakan salah satu metode umum dalam penelitian kualitatif. Dengan memberikan pertanyaan mengenai informasi yang akan diteliti oleh peneliti. Tujuan dari melakukan wawancara tersebut adalah dapat memahami informasi yang disampaikan dari informan.

Peneliti akan melakukan penelitian ini kepada siswi dari ekstrakurikuler di SMK Telekomunikasi Telesandi Bekasi. SMK ini dipilih berdasarkan aksesbilitas dalam pengumpulan data dan kesediaan informan terlibat dalam penelitian. Wawancara dilakukan secara tatap muka dengan memberikan empat pertanyaan dasar. Keempat pertanyaan itu adalah terkait (1) Apakah anda mengetahui sebuah kasus bully yang mengakibatkan kematian terhadap Choi Jin Ri yang akrab dipanggil sulli? (2) Apakah anda merasa kehilangan atas meningganya Sulli?, (3) Apakah sebelumnya anda pernah memposting berita kehilangan mengenai kasus Sulli? Lalu, mengapa anda memposting berita tersebut?, (4) Bagaimana anda merenspons berita duka tersebut?. Setelah wawancara dilakukan, melakukan transkript wawancara, kemudian membuat lampiran coding yaitu open coding, axial coding, dan selective coding.

\section{PEMBAHASAN}

Penelitian ini meneliti suatu kasus yang ada di dalam masyarakat yang dilakukan secara mendalam untuk mempelajari latar belakang, keadaan, dan interaksi yang terjadi. Pengumpulan data dan analisis terjadi secara bersamaan sebagai di seluruh proses teori yang memiliki koneksi ground yang baik, peneliti mengumpulkan informasi dari teks-teks yang masih ada, mengamati, data yang terkumpul, dikodekan dan disortir penemuan, tema, hubungan dan kemudian menarik kesimpulan-kesimpulan dalam sebuah upaya untuk menghasilkan teori konseptual. Setelah melakukan koding, akan ada pertanyaan analisis berupa "ketika, di mana, mengapa, yang, bagaimana, dan dengan konsekuensi apa". Sebuah konsep inti yang muncul adalah bahwa orang- 
orang yang berkabung berduka cita lebih dalam melalui jaringan online dengan orang lain, sehingga membuat duka proses global yang lebih.

Teknik analisis ini mencakup data transcript hasil wawancara mendalam, kemudian peneliti dapat menarik kesimpulan. Dalam penelitian kualitatif, peneliti mendapatkan beberapa temuan yang menggambarkan bagaimana siswi SMK dalam menanggapi Kasus Bullying di Media Sosial Berkabung. Dari hasil wawancara dan observasi peneliti melakukan wawancara kepada 3 informan SMK Telekomunikasi Telesandi yang mengetahui Kasus Kematian Sulli akibat Bullying Media Sosial. Teknik wawancara dilakukan kurang lebih 5-10 menit. Hasil pengumpulan data wawancara dan observasi yang telah diolah dalam bentuk transkrip wawancara dan koding kualitatif. Berdasarkan penelitian yang dilakukan, terdapat 3 selective coding, yaitu berita duka di media sosial, emosional, dan tindak bullying.

Tabel 1. Daftar Informan

\begin{tabular}{|l|l|l|l|l|l|}
\hline NO. & INFORMAN & USIA & $\begin{array}{l}\text { PENGGEMAR } \\
\text { KPOP }\end{array}$ & $\begin{array}{l}\text { MEMBAGIKAN } \\
\text { BERITA DUKA }\end{array}$ & $\begin{array}{l}\text { PERASAAN } \\
\text { EMOSIONAL }\end{array}$ \\
\hline 1. & MDL & $17 \mathrm{Thn}$ & Ya & Tidak & Ya \\
\hline 2. & AZN & $17 \mathrm{Thn}$ & Tidak & Ya & Tidak \\
\hline 3. & II & $17 \mathrm{Thn}$ & Tidak & Tidak & Ya \\
\hline
\end{tabular}

\section{Berita Duka Cita di Media Sosial}

Popular, viral dan booming

Populer atau viral merupakan sebuah informasi atau topik yang disebarluarskan di media sosial kemudian banyak orang yang merespon dan disebarluaskan kembali. Beberapa informan mengatakan bahwa mereka mengetahui berita duka dari kasus Sulli korban bullying sangat popular, viral di berbagai media sosial serta menampilkan sebagai topik teratas pada media sosial karena topik tersebut sangat mengejutkan terutama bagi para penggemar. Informan lebih mengetahui kasus tersebut melalui media sosial bukan dari media massa atau media cetak. Hal ini terkonfirmasi dari informan (MD) yang menyatakan : 'Iya, saya mengetahuinya. Karena berita 
mengenai Sulli sangat viral di media sosial Instagram."(Informan MD; 31 Oktober 2019) dan Informan (II) yang menyatakan : "Iya, saya mengetahui berita tersebut dan kasus Sulli sangat Populer dan booming di media sosial”(Informan II; 31 Oktober 2019).

Media Sosial Instagram

Media sosial Instagram merupakan media yang dapat mengirimkan file berupa foto ataupun video. Di Indonesia merupakan salah satu negara yang masyarakatnya sangat aktif bermain media sosial Instagram (Prihatiningsih, 2017). Instagram memiliki sebuah laporan mengenai para pengguna yang sedang mengalami kedukaan, sehingga para pengguna Instagram dapat mengenang dari foto- foto almarhum. Selain itu, media sosial Instagram dapat mempromosikan sebuah konten. Instagram mempunyai rincian berupa tanggal, lokasi, serta adanya keterangan berupa teks dan visual. Berikut beberapa informan mengatakan bahwa mereka mengetahui topik dari Kasus kematian Sulli melalui media sosial Instagram. Hal terkonfirmasi dari informan (MD) yang menyatakan : "Kalau posting berita mengenai kasus kematian Sulli tidak pernah, saya hanya membaca informasinya saja. Karena beritanya selalu ada di timeline Instagram. Karena, saya penasaran, saya mencari informasi mengenai penyebab kematian Sulli dari berbagai sumber." (Informan MD; 31 Oktober 2019).

Informan tidak pernah memposting mengenai kasus kematian Sulli, tetapi Informan cukup mengetahui kasus tersebut. Selain itu, Informan (II) yang menyatakan : "Saya tidak merepost kasus Sulli, saya hanya mengetahuinya melalui media sosial. Karena beritanya booming, saya hanya membaca informasi dari berbagai sumber dan mencari tahu penyebab kematiannya."(Informan II; 31 Oktober 2019). Sedangkan Informan (AZ) yang menyatakan : "Saya pernah merepost berita mengenai kematian Sulli di story instagram (instastory). Karena sudah banyak kasus bullying di media sosial. Saya hanya ingin memberikan informasi mengenai bullying kepada followers saya. Supaya, tidak ada lagi kasus kematiaan akibat hinaan atau memaki seseorang yang membuat seseorang itu terkena gangguan mental.” (Informan AZ; 31 Oktober 2019). Informan AZ pernah memposting ulang (repost) mengenai kasus kematian Sulli untuk saling mengingatkan kepada followers atau masyarakat luas supaya kejadian tersebut tidak terulang kembali. Sebaiknya, media sosial dipergunakan dengan baik terutama dalam berkomentar di suatu situs jejaring sosial. Tidak dipergunakan untuk menghina seseorang. 


\section{Emosional}

Pada selective coding yaitu Merasa kehilangan, Prihatin dan sedih.

Merasa Kehilangan

Setiap hidup tidak akan terlepas dari yang namanya kehilangan. Kehilangan karena mempunyai tujuan, kehilangan karena memperjuangkan yang saat itu perjuangkan. Kehilangan seperti waktu yang tidak bisa diperoleh kembali pada saat yang sama. Beberapa Informan memang merasakan kehilangan atas kematian Sulli terutama para penggemar Kpop, seperti informan (MD) yang menyatakan :" Semuanya merasa kehilangan atas kematian Sulli, terutama penggemar Kpop seperti saya, dan menurut saya, Sulli merupakan salah satu artis Kpop yang sangat berbakat di dunia hiburan Korea." (Informan MD; 31 Oktober 2019). Dan Informan (II) yang menyatakan :'Walaupun saya bukan seorang Kpopers, tetapi saya sangat merasa kehilangan. Karena Sulli merupakan salah satu aktris kpop multitalenta di dunia hiburan. ” (Informan II; 31 Oktober 2019). Menurut kedua informan, Sulli merupakan aktris yang multitalenta di bidang hiburan, mereka sangat kehilangan atas kematian Sulli.

Prihatin dan sedih merupakan suatu bentuk emosional yang ada di dalam diri manusia sejak lahir. Rasa emosional akan terjadi jika ada respon seperti kesal maka akan timbul rasa marah, bahagia maka akan bahagia, sedih maka akan timbul rasa putus asa dan galau. Informan (MD) yang menyatakan :" Menurut saya, kasus bullying ini sangat memprihatinkan, karena adanya gangguan mental yang diakibatkan oleh komentar negatif terhadap Sulli. Sehingga, Sulli memilih mengakhiri hidupnya dengan cara yang tragis. Di Negara Korea Selatan banyak warganet yang membuat komentar negatif mengenai penampilan seseorang." (Informan MD; 31 Oktober 2019). Menurut Informan MD, penyebab kematian Sulli akibat gangguan mental dalam menghadapi komentar netizen sehingga terjadi rasa keputusasaan yang menyebabkan untuk mengakhiri hidup. Menurut informan (II) yang menyatakan: "Saya turut prihatin mengenai kasus kematian Sulli. Karena warganet hanya menilai dan berkomentar negatif mengenai penampilannya tanpa melihat perilaku yang sebenarnya. "(Informan II; 31 Oktober 2019). Menurut informan II, mereka hanya dapat berkomentar negatif mengenai penampilannya, tanpa melihat yang sebenarnya.

Menurut informan (AZ) yang menyatakan: "Sangat memprihatinkan. Karena kasus kematian Sulli berasal dari gangguan mental yang depresi akibat bully melalui komentar negatif. Sulli lebih memilih mengakhiri hidupnya dengan cara yang tragis, karena sudah merasa putus asa dengan kehidupan yang dijalaninya." (Informan AZ; 31 Oktober 2019). Menurut informan AZ, 
Sulli mengakhiri hidupnya dengan cara bunuh diri, karena merasa putus asa akibat komentar negatif yang menimbulkan gangguan mental (depresi).

\section{Tindak Bullying}

Pada selective coding terdapat bully,netizen yang suka bully.

Bully

Tindakan mengintimidasi seseorang yang dapat dilakukan secara individu atau berkelompok. Tindakan ini biasanya berupa penghinaan terhadap kekurangan yang dimiliki oleh seseorang, seperti penampilan fisik, ras, terlihat lemah, dsb. Kasus kematian yang dialami oleh Sulli, termasuk tindak cyber di dunia maya. Dimana, seorang prilaku mengirimkan serta menyebarkan pesan buruk di dunia maya. Beberapa informan mengatakan bahwa kasus tersebut terjadi karena adanya bully dari haters. Menurut (MD) yang menyatakan: "Sulli memiliki gangguan mental akibat tidak kuat dalam menghadapi serangan netizen yang selalu berkomentar negatif mengenai kehidupannya." (Informan MD; 31 Oktober 2019). Menurut (II) yang menyatakan: "Kasus kematian Sulli yang meninggal karena gangguan mental akibat bullying dari para haters." (Informan II; 31 Oktober 2019).

Netizen yang suka bully

Kata "netizen" terbentuk dari kata "internet" dan "citizen" yang artinya, pengguna aktif dalam berkomunikasi serta mengeluarkan pendapat melalui media sosial. Menurut Informan (MD) yang menyatakan : "Banyaknya komentar negatif dari para netizen mengenai penampilan dan kehidupan Sulli." (Informan MD; 31 Oktober 2019). Netizen yang suka bully selalu memberikan komentar negatif mengenai seorang individu yang tidak disukainya. Netizen akan terus mengajak orang lain atau menghasut orang banyak agar mereka juga tidak menyukai individu tersebut. Sedangkan menurut Informan (II) yang menyatakan: "Para haters yang selalu membully dengan memberikan komentar jahat. Sehingga Sulli memiliki gangguan mental dan lebih memilih untuk mengakhiri hidupnya." (Informan II; 31 Oktober 2019). Dalam kasus bullying seperti ini terdapat individu yang kuat dalam menghadapi bully dan ada yang lemah dalam hal bullying sehingga terjadi gangguan psikis maupun fisik. Individu yang lemah terhadap bully bisa menjadi depresi bahkan dapat mengakhiri hidupnya dengan cara bunuh diri. 


\section{KESIMPULAN}

Penelitian ini mendiskusikan persepsi terhadap fenomena berkabung di media sosial. Terdapat tiga orang informan yang diwawancarai. Dari ketiga informan mengetahui informasi mengenai kasus kematian Choi Jin Ri atau Sulli mantan personil girl band $\mathrm{F}(\mathrm{x})$, karena bullying para haters dari media sosial Instagram. Penelitian ini menemukan tiga kategori utama berdasarkan hasil koding kualitatif. Pertama, berita duka cita di media sosial dapat di akses dan diketahui karena berita tersebut popular, viral dan booming di media sosial Instagram. Bahkan informan ada yang menyebarkan kembali berita tersebut kepada netizen yang lain. Kedua, emosional semua warganet termasuk penggemar Kpop merasakan kehilangan atas kematian Sulli, karena Sulli memilih untuk mengakhiri hidupnya dengan cara yang tragis. Ketiga, tindak bullying Sulli memiliki gangguan mental dalam menghadapi komentar- komentar negatif mengenai kehidupannya hal ini disebabkan karena adanya para haters yang berkomentar negatif. Saat itu kasus kematian Sulli sangat viral di berbagai media sosial termasuk media sosial Instagram. Bahwa media sosial merupakan media yang sangat mudah di akses, sehingga masyarakat dapat lebih mudah mendapatkan informasi dengan cepat. Adapun alasan orang berduka menggunakan media sosial untuk menggambarkan rasa kesedihan yang diungkapkan secara virtual. Berduka cita melalui jaringan internet menjadi sebuah simbol dalam masyarakat. 


\section{DAFTAR PUSTAKA}

Bailey, L., Bell, J., \& Kennedy, D. (2015). Continuing social presence of the dead: Exploring suicide bereavement through online memorialisation. Dikutip dari New Review of Hypermedia and Multimedia. https://doi.org/10.1080/13614568.2014.983554

Brubaker, J. R., Hayes, G. R., \& Dourish, P. (2013). Beyond the Grave: Facebook as a Site for the Expansion of Death and Mourning. Dikutip dari Information Society. https://doi.org/10.1080/01972243.2013.777300

Christensen, D. R., \& Gotved, S. (2015). Online memorial culture: An introduction. Dikutip dari New Review of Hypermedia and Multimedia. https://doi.org/10.1080/13614568.2015.988455

Giaxoglou, K. (2013). R.I.P. man...u are missed and loved by many": entextualising moments of mourning on a Facebook Rest In Peace group site. In Thanatos Journal.

Gibbs, M., Meese, J., Arnold, M., Nansen, B., \& Carter, M. (2015). \#Funeral and Instagram: death, social media, and platform vernacular. Dikutip dari Information Communication and Society. https://doi.org/10.1080/1369118X.2014.987152

Kakar, V., \& Oberoi, N. (2016). Mourning with Social Media: Rewiring Grief. Dikutip dari Indian $\begin{array}{llllll}\text { Journal of Positive Psychology (Vol. 7, } & \text { 371). }\end{array}$ https://doi.org/10.15614/ijpp/2016/v7i3/121833

Meese, J., Gibbs, M., Carter, M., Arnold, M., Nansen, B., \& Kohn, T. (2015). Selfies at funerals: Mourning and presencing on social media platforms. Dikutip dari International Journal of Communication (Vol. 9, pp. 1818-1831).

Moore, J., Magee, S., Gamreklidze, E., \& Kowalewski, J. (2019). Social Media Mourning: Using Grounded Theory to Explore How People Grieve on Social Networking Sites. Omega (United States), 79(3), 231-259. https://doi.org/10.1177/0030222817709691

Neimeyer, R. A., Klass, D., \& Dennis, M. R. (2014). A Social Constructionist Account of Grief: Loss and the Narration of Meaning. Dikutip dari Death Studies. https://doi.org/10.1080/07481187.2014.913454 
Prihatiningsih, W. (2017). Motif Penggunaan Media Sosial Instagram Di Kalangan Remaja. Communication, 8(1), 51. https://doi.org/10.36080/comm.v8i1.651

Swearer, S. M., Collins, A., \& Berry, B. (2012). Bullying. Dikutip dari V. S. Ramachandran (Ed.), Encyclopedia of Human Behavior (Second Edition) (Second Edi, pp. 417-422). https://doi.org/https://doi.org/10.1016/B978-0-12-375000-6.00077-X 